\title{
Rainfall Variability and Droughts in the Drylands of Baringo County, Kenya
}

\author{
Richard Ochieng1* ${ }^{*}$, Charles Recha', Bockline Omedo Bebe ${ }^{2}$, George Morara Ogendi ${ }^{3}$ \\ ${ }^{1}$ Department of Geography, Egerton University, Kenya \\ ${ }^{2}$ Department of Animal Sciences, Egerton University, Kenya \\ ${ }^{3}$ Department of Environmental Sciences, Egerton University, Kenya \\ Email: *snrochieng@gmail.com, charles.recha@egerton.ac.ke, bbebe@egerton.ac.ke,gmorara2009@gmail.com
}

How to cite this paper: Ochieng, R., Recha, C., Bebe, B.O. and Ogendi, G.M. (2017) Rainfall Variability and Droughts in the Drylands of Baringo County, Kenya. Open Access Library Journal, 4: e3827. https://doi.org/10.4236/oalib.1103827

Received: July 14, 2017

Accepted: August 1, 2017

Published: August 4, 2017

Copyright $\odot 2017$ by authors and Open Access Library Inc.

This work is licensed under the Creative Commons Attribution International License (CC BY 4.0).

http://creativecommons.org/licenses/by/4.0/

\section{Open Access}

\begin{abstract}
The study was undertaken to determine rainfall variability and droughts in arid and semi-arid lands (ASALs) of Baringo County. The study used rainfall data for Perkerra Agricultural Research Station (LM5) and Nginyang rainfall station (IL6) for the period 1970-2008 and 1974-2013 respectively. Standardized anomalies were calculated and plotted to establish trends of drought events across the study period. Plots of rainfall data from the two stations displayed an oscillating trend with major rainfall peaks being observed in 1977 and 2007 for Perkerra, 1982 and 1997 for Nginyang. Analysis of rainfall data from the two stations indicates four catastrophic drought periods recognized with standard anomalies of less than -0.9 (SA $(t)<-0.9)$ as a function of the time scales. The study findings reveal that MAM seasonal drought index plots for both Perkerra and Nginyang rainfall stations had a declining long-term MAM seasonal rainfall trend. Perkerra OND Seasonal Drought Index plot indicates a constant trend in the long-term OND seasonal rainfall while Nginyang long-term OND seasonal drought trend shows a gentle upward trend, an indication that the conditions are improving. The study recommends the strengthening of uptake of seasonal climate forecast to inform appropriate decision making regarding response to rainfall variability and drought events.
\end{abstract}

\section{Subject Areas}

Natural Geography

\section{Keywords}

Drought, Standard Anomalies, MAM Rainfall, OND Rainfall 


\section{Introduction}

The present study sought to assess rainfall variability and drought trends in the drylands of Baringo County, Kenya. Baringo County is an arid and semi-arid land with the main source of livelihood being livestock production. The County has witnessed threats of drought events, which negatively affect pastoral livestock assets. The study therefore sought to generate essential information useful in decision making and addressing the effects of drought events to reduce vulnerability among the pastoral livestock farmers. It is only possible to reduce vulnerability to rainfall variability and drought if vital information is accessed and utilized. The uptake of climate information enhances the capacity to adapt. Threats of drought events vary over time and space, calling for more case-focused studies [1]. The present study is anchored on past studies that recommended further research on the use of seasonal climate forecasting by pastoral communities, with keen focus on the pastoralists' ability to access, trust and respond to the forecasts [1] [2].

Occurrence of extreme drought events over the world has become more severe and posed threats to pastoral livestock assets in the recent decades [3]. Studies indicates that on average, $20 \%$ of the land surface is in drought at any given time and the proportion of land surface in extreme drought is predicted to increase from $1 \%$ at present to $30 \%$ by end of the $21^{\text {st }}$ Century [4]. Past drought events led to loss of about $50 \%$ of livestock in Baringo County [5]. Research analysis indicates that there has been little attempt, if any, to comprehensively describe and map various aspects and impacts of a drought as an individual disaster and global multi-faceted phenomenon [6]. Infrastructural development of any country determines the level of its preparedness to drought [6]. Socio-economic drought vulnerability is generally higher throughout Africa since the countries are largely agricultural economies. Long-term droughts coupled with high infrastructural and socio-economic vulnerability contribute to food shortage, malnutrition, disease, conflict and famine in Africa. It is important to map drought vulnerability at smaller administrative subdivisions within countries. This can help generate scientific knowledge base for operational drought tools such as drought monitoring and warning signs forming part of national drought preparedness plans [6].

Drought risks and vulnerability have attracted assessment of drought trends and associated impacts on livestock based livelihoods to reduce vulnerability [5] [6] [7] [8] [9]. These have involved drought monitoring and early warning [9], drought policy and mitigation strategies [10]. In detailed assessments, the meteorological variables are used in the assessment of drought occurrences and effects. They are useful in generating drought indices because they are considered a key element in defining a drought and deciding on the techniques for the analysis. Drought indices describe the severity of drought as compared to the longterm average on normal condition and are usually calculated from one or more variables including: rainfall, temperature, soil water holding capacity and other 
water supply indicators [11] [12]. Despite efforts to strengthen the adaptive capacity, livelihoods in the Arid and Semi-Arid Lands (ASALs) remains vulnerable to drought events associated with climate change and variability.

Kenya has less high potential climate regions of annual rainfall average above $2000 \mathrm{~mm}$ with $80 \%$ of its land mass being arid and semi-arid prone to harsh weather conditions [5] [13]. The country has in the past experienced repeated droughts during the years: 1975, 1977, 1980, 1983/84, 1991/92, 1995/96, 1999/ 2000, 2004, 2008 and 2009/2010. These drought droughts that affected 16000, 20,000, 40,000, 200,000, 1.5 million, 4.4 million, 3 million, 1.4 million, 1.4 million and 10 million people respectively. Severe droughts occurred in 1984, 1980 and $1991 / 1992$ claiming $64.8 \%, 42 \%$ and $33.6 \%$ of livestock respectively [5] [14] [15] [16] [17] [18]. The occurrence of drought events and the impacts across the recorded years lays the foundation for more drought studies to help generate adequate climate information on rainfall variability and drought trends, enhance adaptive capacity and reduce vulnerability.

\section{Study Area}

Baringo County (Figure 1) is located within the Rift Valley of Kenya, between longitudes $35^{\circ} 30^{\prime}$ and $36^{\circ} 30^{\prime}$ East and between latitudes $0^{\circ} 10^{\prime}$ South and $1^{\circ} 40^{\prime}$ North. The County covers an area of $11,090 \mathrm{Km}^{2}$ with a population of 555,561 persons in 110,649 households. The Agro-ecological zones in the county are: UH 1, UH 2, LH 2, LH 3, UM 3, UM 4, UM 5, LM 4, LM 5, LM 6 and IL 6. Temperatures range from a minimum of $10^{\circ} \mathrm{C}$ to a maximum of $35.0^{\circ} \mathrm{C}$ with bimodal rainfall pattern of long rains (MAM) and short rains (OND) which range from 300 to $700 \mathrm{~mm}$ in the lowlands and $1200 \mathrm{~mm}$ in the highlands [19] [20] [21].

Desert shrubs with drier thorny acacia trees and thorny bushes characterize

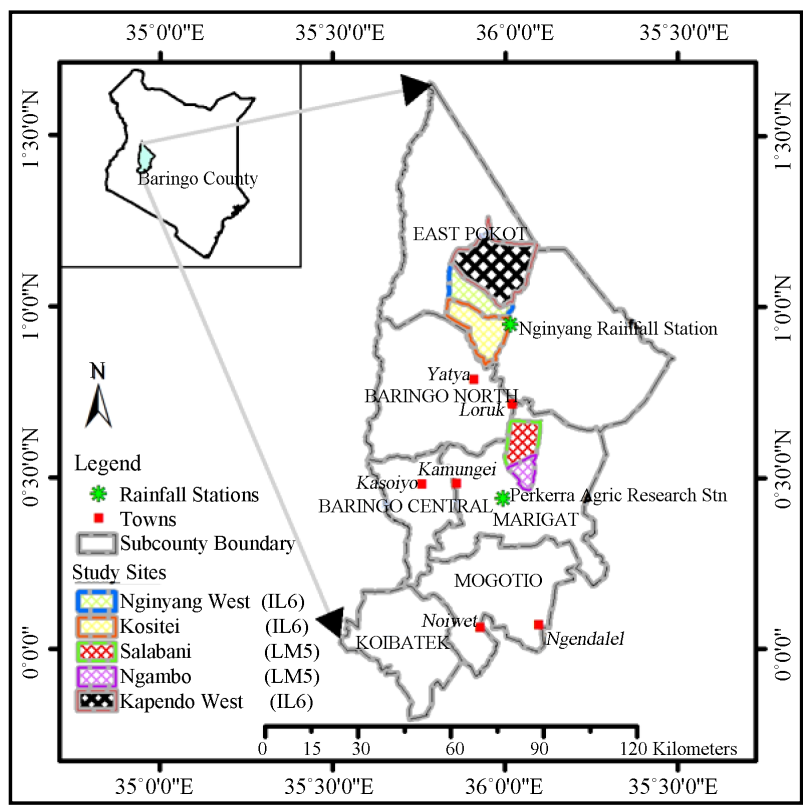

Figure 1. Map showing study locations and rainfall stations. 
Baringo County. In the Southern part of the county are small patches of grasslands with temperate forests and evergreen forests composed of semi deciduous bushes and wooded [5]. Livestock assets are central in the livelihoods whether in pastoral, agro-pastoral, mixed and marginal farming systems in the Baringo County. The main livestock in the County include the East African Zebu cattle in the lowlands and exotic cattle in the highlands. The crops grown in the county are: maize, finger millet, sorghum, beans, cowpeas, green grams, Irish potatoes and sweet potatoes [22]. Despite the diversity of agro-ecological zones and livelihood support system, the study site was limited to AEZs LM5 and IL6. The two agro-ecological zones were purposely choses as the study targeted the extreme semi-arid and arid parts of Baringo County. Overall, the choice of Baringo County was informed by the significance of the Arid and semi-arid lands in the economic development of the country and as an area that has in the past experienced massive loss of livestock due to rainfall variability and drought events.

\section{Materials and Methods}

\subsection{Rainfall Data}

Rainfall data for the two stations: Perkerra and Nginyang rainfall station was obtained from Kenya Meteorological Services. Perkerra and Nginyang rainfall stations had data for the period 1970-2008 and 1974-2013 respectively. The choice of the rainfall station was influenced by agro-ecological stations and amount of missing data. The two stations are located within the study sites agroecological zones LM5 and IL6. The percentage of missing rainfall data in the two stations was less than $10 \%$ and the data spans over 20 years hence meeting the requirements of World Meteorological Organization with regard to climatological analysis.

The study used imputation to fill in missing rainfall data. Multiple imputations method was used to overcome underestimation of standard errors and confidence intervals typical of single imputation [23]. The method involves replacing missing data with substituted values. The imputed data sets were combined and average worked out. The method involves estimation of missing rainfall data from the observations of rainfall (rainfall data sets) at the same station and period but different years.

The missing rainfall data $P_{X}$ was estimated using the following formula:

$$
P x=1 / n \sum_{i=1}^{i=n} P i
$$

where:

$n=$ the number of rainall data sets

$P i=$ rainfall data from the $i$ th data set

$P_{X}=$ missing rainfall data

\subsection{Methods}

The study estimated standardized anomalies (drought index) from rainfall data 
using the formula:

$$
S A(t)=\frac{\{S P(t)-\mu\}}{\{\sigma\}}
$$

where:

$S A(t)=$ time-series of standardized anomalies

$S P(t)=$ cumulative precipitation during the season

$\mu=$ represents mean

$\sigma=$ standard deviation

The interpretation of Standard Anomalies was based on World Bank (2013) definition:

Anomaly lower than $-0.9=$ Catastrophic drought

Anomaly between -0.9 and $-0.6=$ Severe drought

Anomaly above $-0.6=$ Not severe

The indices were plotted to generate time series graphs and determine trends of drought events within the study period.

To ascertain whether there was a correlation between the total annual rainfall and the annual drought indexes-SA(t), a correlational analysis was done and a plot presented to display the relationship.

\section{Results and Discussion}

\subsection{Rainfall Trends in Baringo County}

An oscillating trend of rainfall with four major positive peaks was observed in 1977, 1988/89, 1997 and 2007 while very low mean annual rainfall was recorded in $2000(21.4 \mathrm{~mm})$ and in $2002(19.8 \mathrm{~mm})$ with a general declining rainfall trend from 1970 to 2008 periods in Perkerra (Figure 2(a)). This provides a strong signal that drought events have occurred and are likely to reoccur.

On the other hand, the year-to-year annual rainfall variations in IL6 zone showed significant anomalies in annual rainfall between 2000 and 2010 (Figure 2(b)). Nginyang rainfall station shows an oscillating trend with major rainfall peaks observed in 1982 and 1997, and others in 1979, 1981 and 1985. The results concur with the findings of [24], an analysis of extreme climatic events in Kenya that estimated long-term annual mean of $23.52 \mathrm{~mm}$. Very low rainfalls (3.29 to $13.33 \mathrm{~mm}$ ) far much below the long-term annual average featured in 1974, 1976, 1980, 1991, 1996, 1999, 2000 and 2009 which corresponds to the years Kenya experienced widespread drought with a decreasing trend of total annual rainfall (Figure 2(b)) in the study area (IL6). This indicates that the area will continue to become drier over time, increasing vulnerability if appropriate response strategies are not identified and implemented. Drought events in Congo in the years 1970s, 1980s and 1990s, corresponds with the period that Nginyang registered very low rainfall [25]. This finding indicates that drought can be widespread and can cut across both national and international boundaries, requiring trans-national mitigation and adaptation approaches. Drought trends in Burkina Faso, 


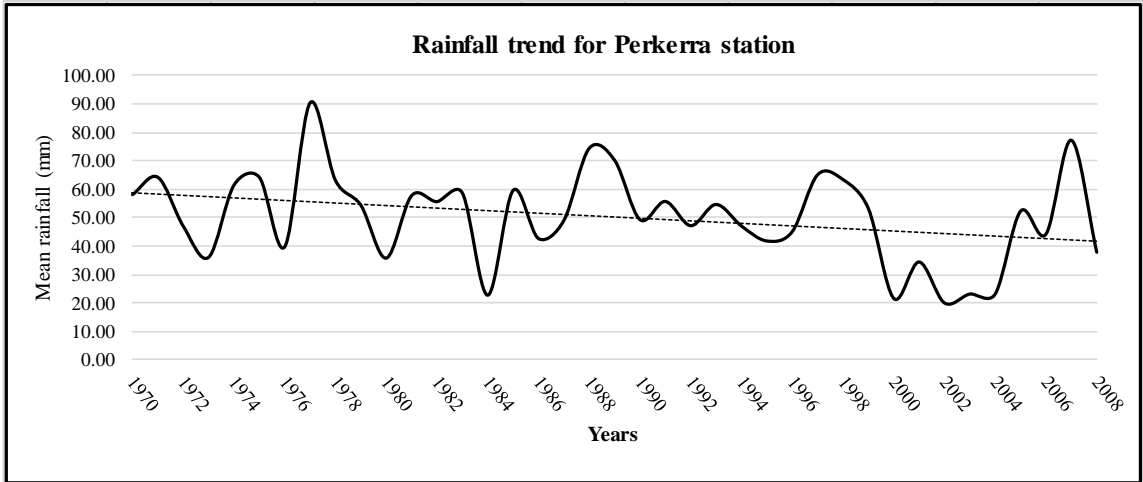

(a)

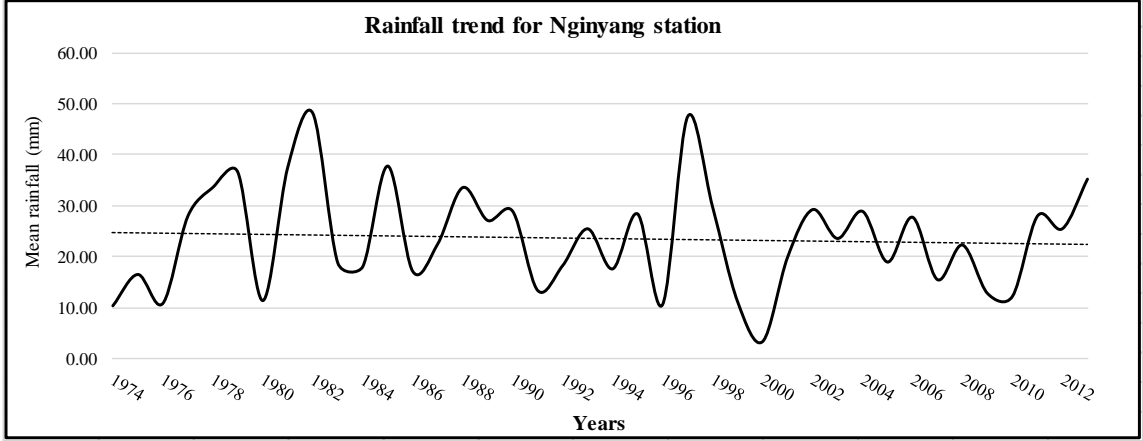

(b)

Figure 2. (a) Mean annual rainfall for Perkerra rainfall station; (b) mean annual rainfall for Nginyang rainfall station.

Ghana, Mali, Togo and Volta Basin supports this finding by indicating that frequency of dry years have increased in Africa but occur at relatively shorter intervals [26].

The results of rainfall variability imply that pastoralists have planned adaptation strategies implemented to secure their livestock assets from drought event effects. The information is informative and significant in guiding decision making in relation to pastoral livestock production in arid and semi-arid Baringo County.

\subsection{Analysis of Annual Drought Index}

Figure 3(a) \& Figure 3(b) presents a plot generated from the annual drought index for Perkerra and Nginyang Rainfall Station. On a time-scale of 12-month (annual), for the period 1970-2008, four extremely catastrophic drought periods were observed: 1984, 2000, 2002 and 2004 with standard anomalies less than $-0.9(\mathrm{SA}(\mathrm{t})<-0.9)$ as a function of the time scales in Perkerra (Figure 3(a)). Other noticeable catastrophic drought events were 1972/1973, 1976, 1980, 1986, 1995/1996, 2001, 2003, 2006 and 2008 with standard anomalies less than -0.9 as a function of the time scales. Apart from the case of year 2003 and 2008, these results concur with the findings of [24] on extreme climatic events for economic development in Kenya. The two cases of year 2003 and 2008 can be attributed to 


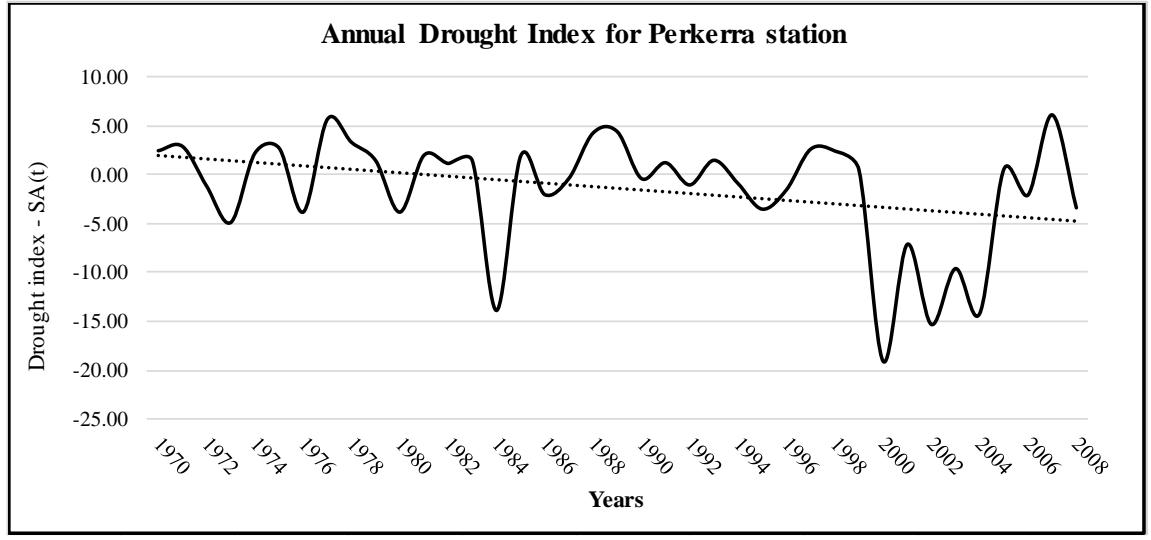

(a)

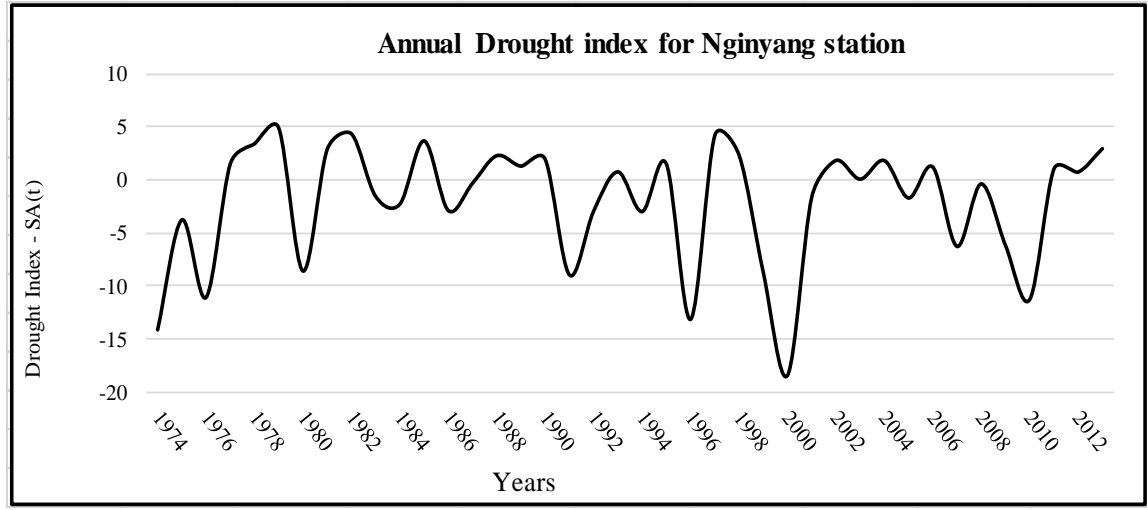

(b)

Figure 3. (a) Annual drought index for Perkerra rainfall station; (b) annual drought index for Nginyang rainfall station.

locational variation in drought events in place and time. Similar findings were recorded in Morocco, a county that experienced catastrophic drought in 1984 and 1999-2003 [27]. Studies registered the most severe droughts during the period 1999-2002 in Morocco, Algeria and Tunisia, results that corroborates the present study [28] [29]. This is an indication that the drought event did not only affect Baringo County, but also different parts of Africa. It also signifies spatio-temporal nature of drought events and associated impacts.

Noticeably, all the catastrophic drought events were preceded by high rainfall events (Standard Anomalies greater than 1, SA(t) $>1.00$ ). This phenomenon takes place when sea surface temperature in oceans increases anomaly, causing sudden heavy rainfall and thereafter rainfall decreases drastically followed by a prolonged severe dry spell [30]. The effect can be seen in two forms, increasing then suddenly decreasing rainfall amount. For instance, the catastrophic drought event in 2000-2004 period that was preceded by the El Niño rains in 1997-1998 and has been classified by many experts as the worst El Niño effect in 20th century. Previous studies established very severe seasonal never span over many years in Africa, a finding that concurs with the results of drought analysis for the present study [31]. The obtained drought indexes show breaks between succes- 
sive drought events in the study area.

The Nginyang station data on a time scale of 12-month (annual) reveals five catastrophic drought periods in the study area observed in 1974, 1976, 1996, 2000 and 2010 period (Figure 4(b)). All these periods indicated standard anomalies less than $-0.9(\mathrm{SA}(\mathrm{t})<-0.9)$ as a function of the time scales. Noticeable severe drought events were observed in 1980, 1999 and 1991 with standard anomalies between -0.9 and -0.6 as a function of the time scales (Figure 4(b)). Studies attributed the 1970s and 1980s droughts experienced in Western AfricaSahel to southward shift of the warmer sea surface temperatures in the Atlantic and warming in the Indian ocean [32]. The Ethiopia and Somalia drought is attributed to Indian Ocean sea temperatures that influenced the East African rainfall [31] [33] [34].

Correlation analysis results between the annual rainfall and the drought indexes-SA $(t)$ had higher and positive correlation in Perkerra $(r=0.9218)$ rainfall station which depicts a strong positive correlation between the total recorded annual rainfall and the annual standardized drought anomaly indexes $S A(t)$ as

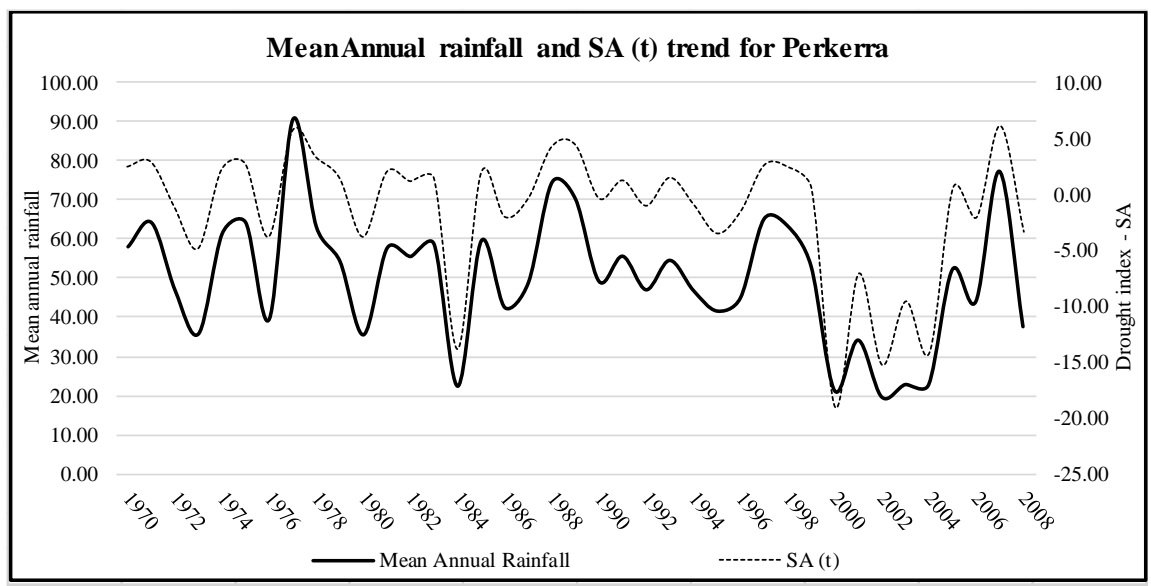

(a)

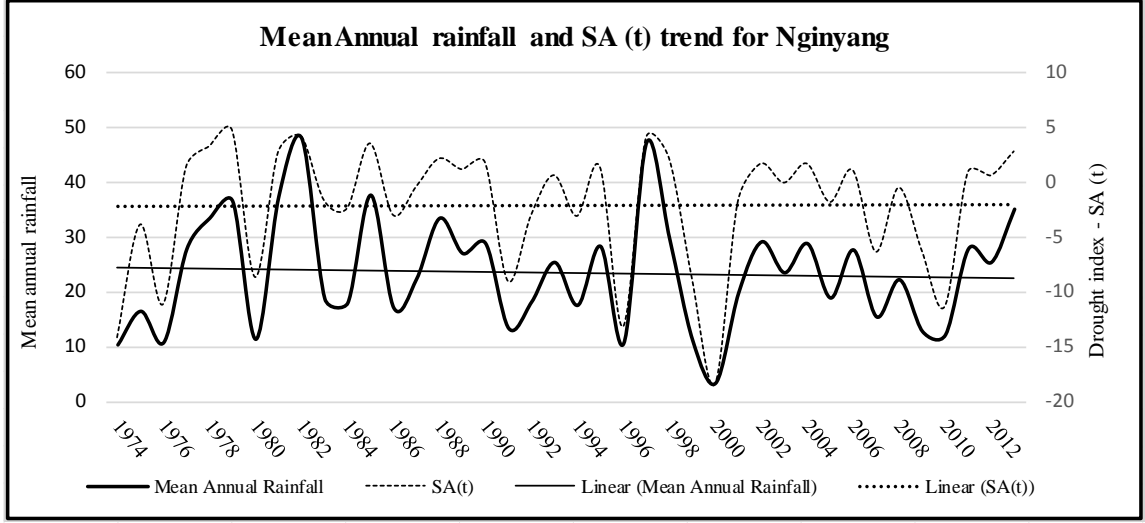

(b)

Figure 4. (a) Relationship between mean annual rainfall and annual drought indexes for Perkerra rainfall station; (b) relationship between mean annual rainfall and annual drought indexes for Nginyang rainfall station. 
illustrated in Figure 4(a). This test was important to justify the use of drought index from rainfall amounts. It also helps to establish that drought events are directly influenced by rainfall received.

Similarly, correlation analysis results between the annual rainfall and the drought indexes-SA(t) in Nginyang also posted a positive correlation $(\mathrm{r}=$ 0.6879 ) (Figure 4(b)). This result is significant in analyzing effects of drought in livestock asset. This is an indication that severity of drought increases with decrease in rainfall amount.

\subsection{Seasonal Drought Index}

The plots for the March-April-May (MAM) and October-November-December (OND) seasonal drought index-SA(t) for the variation of rainfall in 1970-2008 periods for the two stations are shown in Figure 5(b) and Figure 6(b) and over the period 1974-2013 is shown in Figure 5(b) and Figure 6(b).

The MAM Seasonal Drought Index plot for Perkerra rainfall station shows intermittent trend of drought events with peaks observed in the years 1979, 1983, 2000 and 2005 and a declining trend indicating drier conditions, which implies that the region is vulnerable to drought events (Figure 5(a)).

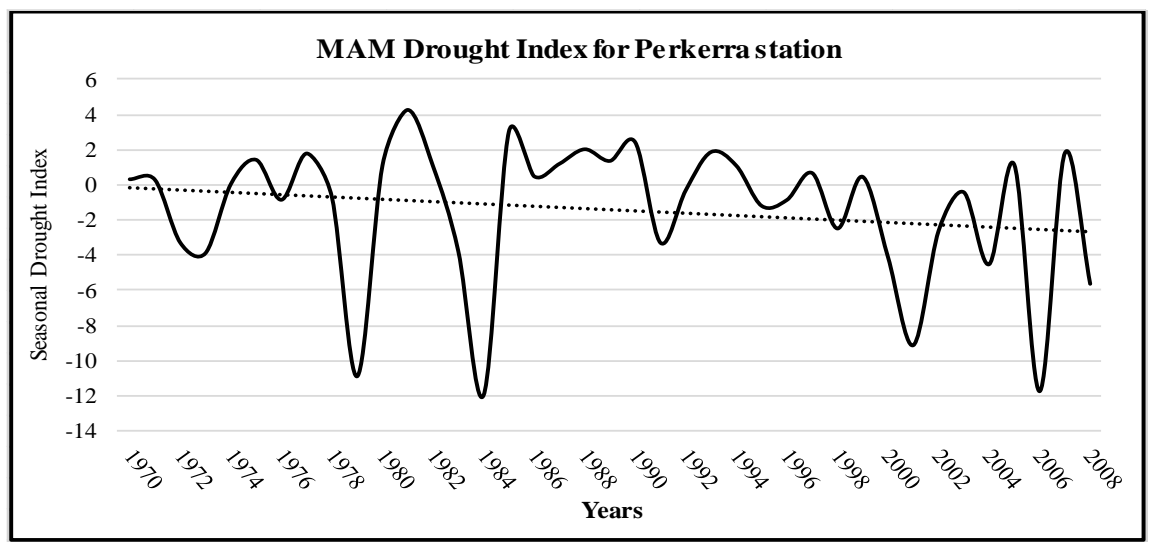

(a)

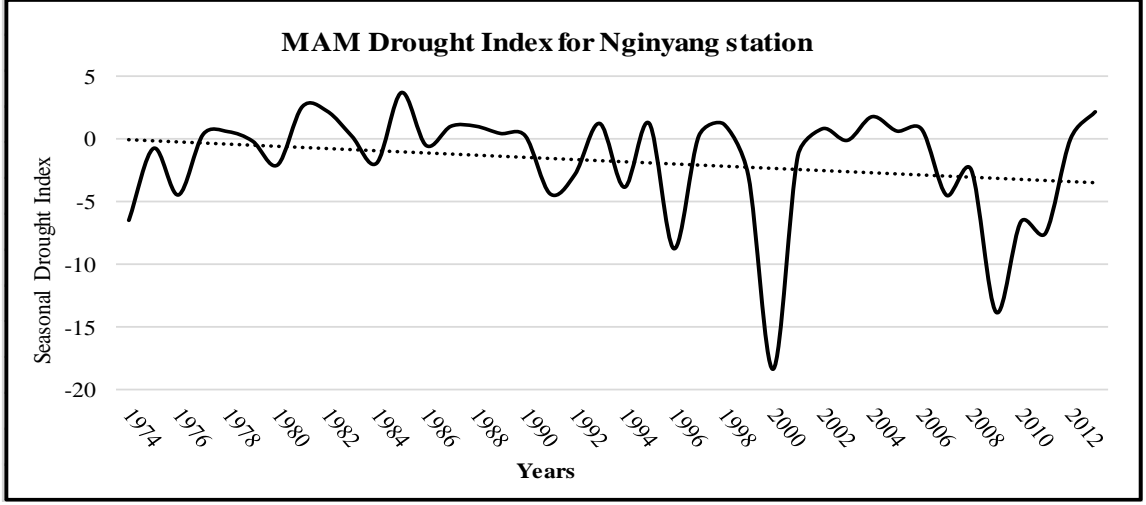

(b)

Figure 5. (a) March-April-May (MAM) drought index for Perkerra rainfall station; (b) March-April-May (MAM) drought index for Nginyang rainfall station. 


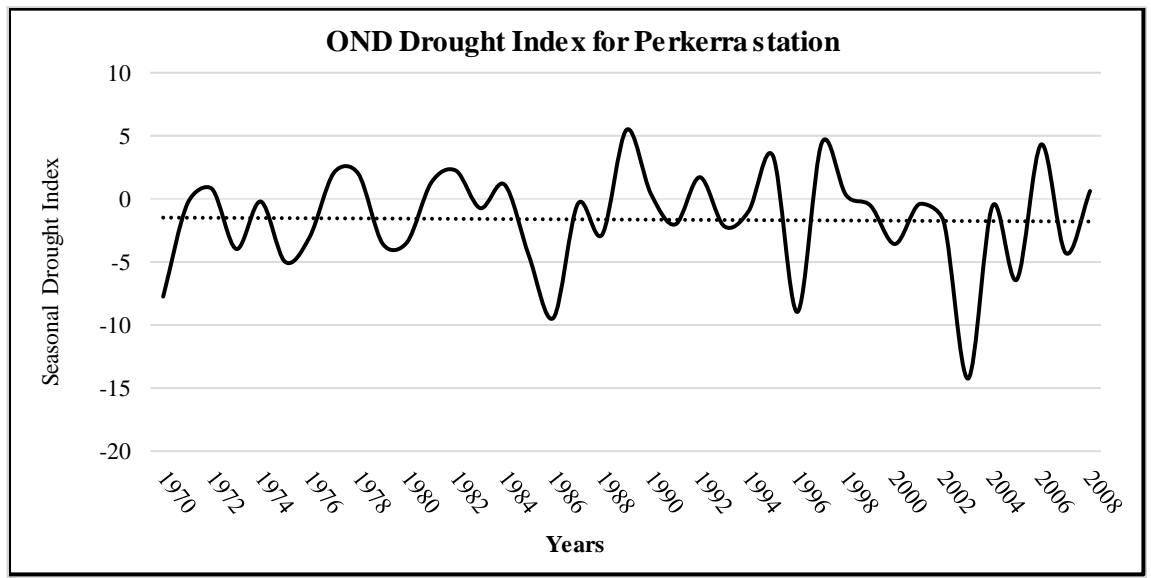

(a)

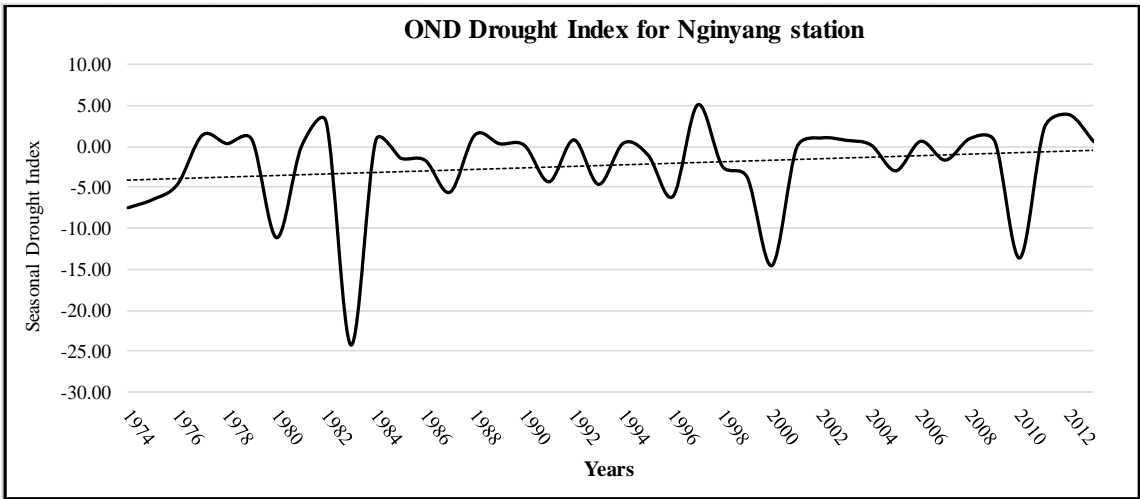

(b)

Figure 6. (a) Oct-Nov-Dec (OND) drought index for Perkerra rainfall station; (b) OctNov-Dec (OND) drought index for Nginyang rainfall station.

The MAM Nginyang Seasonal Drought Index plot shows fluctuating trend of drought events with drought peaks observed in the years 2000 and 2009 and others visible in the years 1974, 1996, 2010 and 2011. The long-term MAM seasonal trend for rainfall shows a declining trend, which is an indication of drier conditions over long time scale and implies vulnerability of the region to drought (Figure 5(b)). This finding corroborates [34], which revealed a statistically significant increase in drought for the African continent during the period 1901-2011.

The OND Seasonal Drought Index plot for Perkerra station shows few drought events with the major drought event peak being observed in the years 2003 (Figure 6(a)) with smaller peaks in the years 1985 and 1996. Compared to the MAM Seasonal Drought Index plot, the OND season seems to be having fewer drought events for the 39-year period for Perkerra rainfall station. Noteworthy, from the OND Seasonal Drought Index plot, it was deduced that the long-term OND seasonal trend for rainfall shows a constant trend of below mean rainfall for Perkerra rainfall station (Figure 6(a)).

On the other hand, the OND Seasonal Drought Index plot also shows a fluc- 
tuating trend of drought events in Nginyang with catastrophic drought events being observed in years 1980, 1983, 2000 and 2010 (Figure 6(b)). Severe drought peaks include: year 1974, 1974 and 1996. Compared to the MAM Seasonal Drought Index plot, the OND season seems to have more catastrophic drought events for Nginyang rainfall station. However, from the OND Seasonal Drought Index plot, it can be observed that the long-term OND seasonal drought trend shows a gentle upward trend, an indication that the conditions are improving. The trend indicates that Nginyang station rainfall totals with time is likely to display an upward trend with improving drought conditions. Drought impacts negatively on food security and pastoral livestock production, calling for an integrated approach that is geared towards a shift from crisis management to risk management approaches that includes use of early warning systems and seasonal climate forecasts [25] [34] [35].

Comparing the two regions, Perkerra and Nginyang, Perkerra is getting drier compared to Nginyang across the study period. This can be attributed to the generally improving conditions of Nginyang during the OND seasons across the study period. Across all the seasons, Perkerra MAM is getting drier as depicted by the relatively sharp dip in the plot. This is an alarming situation calling for more attention. MAM being the main season in the study area, the Perkerra livelihood is likely to be significantly affected.

\section{Conclusion}

The analysis of rainfall variability and drought trends established that the study area is prone to high rainfall variability, catastrophic and severe droughts. The findings indicate that drought events in the study area were common in the study area over the period 1970-2013. On average, rainfall data from the region indicate decreasing trends in the total annual rainfall over the study period an indication that the area will continue to become drier over time.

\section{Recommendations}

The study therefore recommends that the information generated is passed to the pastoral community in the study area to enable them understand the actual situation in regard to rainfall variability and drought events. This will be useful in identification and uptake of appropriate adaptation strategies to reduce rainfall variability and drought vulnerability among the pastoralists. More so, Kenya meteorological department should assist in establishment, equipping and recruitment of trained personnel in the local weather stations to improve acquisition and management of high-resolution climate data. Intensified dissemination and use of early warning information by multiple stakeholders would help reduce community vulnerability.

\section{References}

[1] Morton, J.F. (2007) The Impact of Climate Change on Smallholder and Subsistence 
Agriculture. Proceedings of the National Academy of Sciences, 104, 19680-19685. https://doi.org/10.1073/pnas.0701855104

[2] O’Brien, K. and Vogel, C.H. (2003) Coping with Climate Variability: User Responses to Seasonal Climate Forecasts in Southern Africa. Ashgate, Burlington, VT.

[3] Cancelliere, A., Di Mauro, G., Bonaccorso, B. and Rossi, G. (2007) Drought Forecasting Using the Standardized Precipitation Index. Water Resources Management, 21, 801-819. https://doi.org/10.1007/s11269-006-9062-y

[4] Burke, E.J., Brown, S.J. and Christidis, N. (2006) Modelling the Recent Evolution of Global Drought and Projections for the Twenty-First Century with the Hadley Centre Climate Model. Journal of Hydrometeorology, 7, 1113-1125. https://doi.org/10.1175/JHM544.1

[5] Homewood, K. and Lewis, J. (1987) Impacts of Drought on Pastoral Livestock in Baringo Kenya 1983-85. Journal of Applied Ecology, 24, 615-631. https://doi.org/10.2307/2403897

[6] Eriyagama, N., Smakhtin, V.Y. and Gamage, N. (2009) Mapping Drought Patterns and Impacts. A Global Perspective (Vol. 133). International Water Management Institute, Colombo.

[7] Wilhelmi, O.V., Hubbard, K.G. and Wilhite, D.A. (2002) Agro-Climatological Factors Influencing Vulnerability to Agricultural Drought: A Nebraska Case Study. International Journal of Climatology, 22, 1399-1414. https://doi.org/10.1002/joc.796

[8] Brunetti, M., Maugeri, M., Nanni, T. and Navarra, A. (2002) Droughts and Extreme Events in Regional Daily Italian Precipitation Series. International Journal of Climatology, 22, 543-558. https://doi.org/10.1002/joc.751

[9] Svoboda, M., LeComte, D., Hayes, M. and Heim, R. (2002) The Drought Monitor. Bulletin of the American Meteorological Society, 83, 1181. https://doi.org/10.1175/1520-0477(2002)083<1181:TDM>2.3.CO;2

[10] Brown, M.E., Pinzon, J.E. and Prince, S.D. (2006) The Effect of Vegetation Productivity on Millet Prices in the Informal Markets of Mali, Burkina Faso and Niger. Climate Change, 78, 181-202. https://doi.org/10.1007/s10584-006-9096-4

[11] Hayes, M.J. (2003) Drought Indices. National Drought Mitigation Center.

[12] Keyantash, J. and Dracup, J.A. (2002) The Quantification of Drought: An Evaluation of Drought Indices. Bulletin of the American Meteorological Society, 83, 1167. https://doi.org/10.1175/1520-0477(2002)083<1191:TQODAE >2.3.CO;2

[13] Kaimba, G.K., Njehia, B.K. and Guliye, A.Y. (2011) Effects of Cattle Rustling and Household Characteristics on Migration Decisions and Herd Size Amongst Pastoralists in Baringo District, Kenya. Pastoralism: Research, Policy and Practice, 1, 18. https://doi.org/10.1186/2041-7136-1-18

[14] Bollig, M. (2006) Risk Management in a Hazardous Environment: A Comparative Study of Two Pastoral Societies, Springer Verlag, Berlin. https://doi.org/10.1007/978-0-387-27582-6

[15] Ellis, J. and Swift, D. (1988) Stability of African Pastoral Ecosystems: Alternate Paradigms and Implications for Development. Journal of Range Management, 41, 450-459. https://doi.org/10.2307/3899515

[16] Andassa, A. and Oba, G. (2007) Relating Long-Term Rainfall Variability to Cattle Population Dynamics in Communial Rangelands and a Government Ranch in Southern Ethiopia. Agricultural Systems, 94, 715-725. https://doi.org/10.1016/j.agsy.2007.02.012

[17] ILRI (2010) An Evaluation of the Response to the 2008-2009 Drought in Kenya. In- 
ternational Livestock Research Institute, Nairobi.

[18] Lesorogol, C.K. (2008) Land Privatization and Pastoralist Well-Being in Kenya. Development and Change, 39, 309-331. https://doi.org/10.1111/j.1467-7660.2007.00481.x

[19] Jaetzold, R., Schmidt, H., Hornetz, B. and Shisanya, C. (2007) Farm Management Handbook of Kenya: Part C, East Kenya, 2, Ministry of Agriculture, Nairobi.

[20] Republic of Kenya (2010) Kenya National Bureau of Statistics: 2009 Kenya Population and Housing Census, Volume 1A. Government Printers, Nairobi.

[21] Republic of Kenya (2013) Baringo County Budget Implementation Report. Government Printers, Nairobi.

[22] Republic of Kenya (2014) Baringo County Government Annual Development Plan 2015/16. Government Printers, Nairobi.

[23] Radi, N.F.A., Zakaria, R. and Azman, M.A.Z. (2015) Estimation of Missing Rainfall Data Using Spatial Interpolation and Imputation Methods. The 2nd Ism International Statistical Conference 2014 (ISM-II): Empowering the Applications of Statistical and Mathematical Sciences, 1643, 42-48. https://doi.org/10.1063/1.4907423

[24] Huho, J.M. and Kosonei, R.C. (2014) Understanding Extreme Climatic Events for Economic Development in Kenya. IOSR Journal of Environmental Science, Toxicology and Food Technology, 8, 14-24. https://doi.org/10.9790/2402-08211424

[25] Vicente-Serrano, S.M., Beguería, S., Gimeno, L., Eklundh, L., Giuliani, G., Weston, D., El Kenawy, A., López-Moreno, J.I., Nieto, R., Ayenew, T., Konte, D., Ardö, J. and Pegram, G.G.S. (2012) Challenges for Drought Mitigation in Africa: The Potential Use of Geospatial Data and Drought Information Systems. Applied Geography, 34, 471-486. https://doi.org/10.1016/j.apgeog.2012.02.001

[26] Kasei, R., Diekkrüger, B. and Leemhuis, C. (2010) Drought Frequency in the Volta Basin of West Africa. Sustainability Science, 5, 89-97. https://doi.org/10.1007/s11625-009-0101-5

[27] Ouassou, A., Ameziane, T., Ziyad, A. and Belghiti, M. (2007) Application of the Drought Management Guidelines in Morocco. Options Méditerranéennes, Series B, 58, 343-372.

[28] Touchan, R., Anchukaitis, K.J., Meko, D.M., Attalah, S., Baisan, C. and Aloui, A. (2008) Long Term Context for Recent Drought in North-Western Africa. Geophysical Research Letters, 35, Article ID: L13705. https://doi.org/10.1029/2008GL034264

[29] Touchan, R., Anchukaitis, K.J., Meko, D.M., Sabir, M., Attalah, S. and Aloui, A. (2011) Spatiotemporal Drought Variability in North-Western Africa over the Last Nine Centuries. Climate Dynamics, 37, 237-252. https://doi.org/10.1007/s00382-010-0804-4

[30] Fyfe, J.C., Boer, G.J. and Flato, G.M. (1999) Arctic and Antarctic Oscillations and Their Projected Changes under Global Warming. Geophysical Research Letters, 26, 1601-1604. https://doi.org/10.1029/1999GL900317

[31] Dutra, E., Magnusson, L., Wetterhall, F., Cloke, H.L., Balsamo, G., Boussetta, S., I Pappenberger, F. (2013) The 2010-2011 Drought in the Horn of Africa in ECMWF Reanalysis and Seasonal Forecast Products. International Journal of Climatology, 33, 1720-1729. https://doi.org/10.1002/joc.3545

[32] Dai, A., Trenberth, K.E. and Qian, T. (2004) A Global Dataset of Palmer Drought Severity Index for 1870-2002: Relationship with Soil Moisture and Effects of Surface Warming. Journal of Hydrometeorology, 5, 1117-1130.

https://doi.org/10.1175/JHM-386.1 
[33] Tierney, J.E., Smerdon, J.E., Anchukaitis, K.J. and Seager, R. (2013) Multi-Decadal Variability in East African Hydro-Climate Controlled by the Indian Ocean. Nature, 493, 389-392. https://doi.org/10.1038/nature11785

[34] Masih, I., Maskey, S., Mussa, F.E.F. and Trambauer, P. (2014) A Review of Droughts on the African Continent: A Geospatial and Long-Term Perspective. Hydrology and Earth System Sciences, 18, 3635-3649. https://doi.org/10.5194/hess-18-3635-2014

[35] Tadesse, T., Haile, M., Senay, G., Wardlow, B.D. and Knutson, C.L. (2008) The Need for Integration of Drought Monitoring Tools for Proactive Food Security Management in Sub-Saharan Africa. Natural Resources Forum, 32, 265-279. https://doi.org/10.1111/j.1477-8947.2008.00211.x

Submit or recommend next manuscript to OALib Journal and we will provide best service for you:

- Publication frequency: Monthly

- 9 subject areas of science, technology and medicine

- Fair and rigorous peer-review system

- Fast publication process

- Article promotion in various social networking sites (LinkedIn, Facebook, Twitter, etc.)

- Maximum dissemination of your research work

Submit Your Paper Online: Click Here to Submit

Or Contact service@oalib.com 